\title{
Development of Inclusive Kampung Settlement in the Activity Center Area in Krian, Sidoarjo, Indonesian Case Study
}

\author{
Dana Wahyu Prismawan ${ }^{1}$ Purwanita Setijanti $^{2}$ Muhammad Faqih $^{3}$ \\ Department of Architecture \\ Ten November Institute of Technology \\ Surabaya \\ Indonesia
}

\begin{abstract}
Urbanization has the potential to create inequality and exclusion in economic development and development and lead to slums. Slums can also occur because residents are unable to meet basic housing basic needs. This phenomenon also occurs in Krajan Pasar Kampung - Krian which is located around the center of the area. However, slums have potential for their inhabitants from the social and economic side. The importance of handling slums in the context of sustainable development has become a global issue.

This research aims to determine the strategies of inclusive development in slum upgrading on public facilities and application of inclusive development principles.

This research is a descriptive case study, used a mixed methods approach, and uses SWOT analysis. Based on the research results, it is known that the concept of inclusive development consists of; improving the quality and provision of public facilities; increasing performance of accessibility, affordability, resilience, and sustainability; and cooperate with the of Krian's Market manager in slum upgrading.
\end{abstract}

Key Words: Inclusive Development, Slum, Kampung, Krian

\section{INTRODUCTION}

One indication of the development of urban areas is the increasing number of residents, both residents who come from natural growth or urbanization process. When handled properly, urbanization has the potential to create opportunities for a better life, providing a way out of poverty and acting as an engine of economic growth. However, urbanization can also increase inequality and exclusion within the city can prevent developmental progress (http://www.worldbank.org/en/topic/inclusive-cities). Lack of affordable land, access to services, and economic opportunities, increasingly leads to the rise of the urban poor to informal settlements with inadequate service and exclusivity. It increases inequality and thus requires special attention to achieve inclusion in urban areas (World Bank, 2015).

Urbanization has triggered high demand for housing, employment and pressure on existing urban infrastructure as well as linked to the emergence of slum settlements (Joshua and Glanda, 2016). Besides, slums can be formed because residents or local communities are unable to meet basic infrastructure needs in residential environments.

On other hand, slums have advantages or positive values for the inhabitants. According to Elrayies (2016), slums are still attractive for people to stay and find work. In developing countries, slums are often home to an abundance of labor in a city. In addition, the slums are able to provide shelter / shelter, jobs and livelihood expectations for Low-Income Communities.

Krajan Pasar Kampung (traditional settlements) in Krian, Sidoarjo is a slum area around the center of activity and trade area (Krian's Market). The slum areas are also listed in the District Government Decree on the priority slum areas to be addressed. Krian has a rapid development, this is related to its function as an activity center of sub-district as well as supporting the main urban center of Sidoarjo Regency. In addition, Krian also affected from the development of Surabaya and Sidoarjo city, the occurrence of urbanization and employment opportunities (industry and trade activities).

Slum upgrading has become an international issue, such as in Sustainable Development Goal's (SDG's) and New Urban AgendaHabitat III (NUA). In the target SDG's several related points are the welfare (point 3) of universal access to drinking water and proper sanitation (point 6), decent and sustainable settlements (point 11). While in the NUA, one of the urgencies in the future development of 2030 is expected urban urban city can ensure ease of access for all, safe and affordable housing and basic services, an increase in slum areas. 
Therefore, the importance of slum upgrading, the issue of sustainable development, the potential of slum areas for the inhabitants from the social and economic side, as well as in efforts to reduce inequality and exclusion in economic development and development it is necessary to develop a concept that is able to integrate some of these things. In parallel, inclusivity requires access to affordable needs, such as housing and basic services, which are often a heavy burden for many disadvantaged households (World Bank, 2015). It also complies with one of the goals of SDG's on point 11 of calling for inclusive, safe, resilient and sustainable cities. This research aims to determine the strategies of inclusive Krajan Pasar Kampung development in slum upgrading, especially on public or communal facilities and application of inclusive development principles

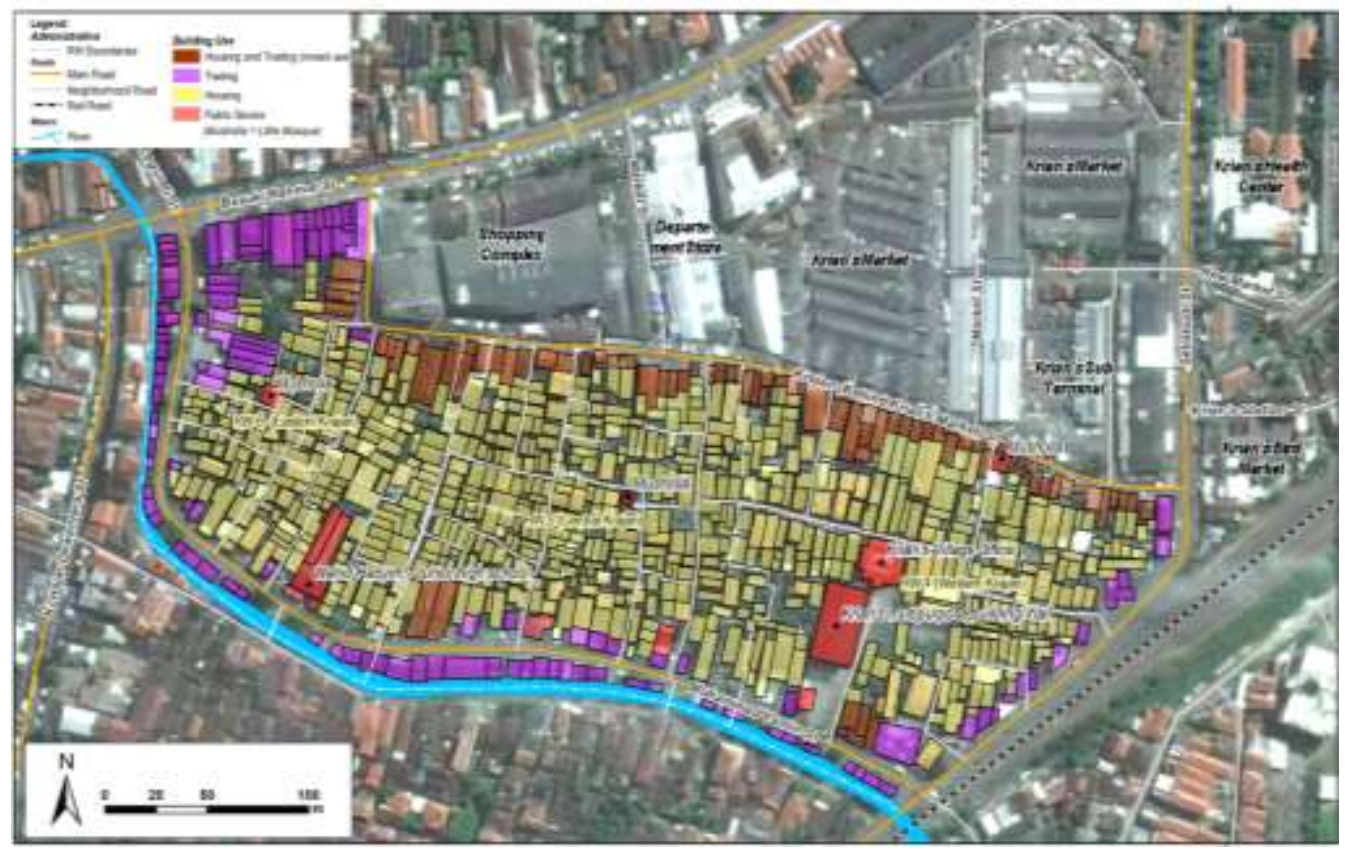

Figure 1.1 Krajan Pasar Pasar Kampung’s Map

\section{THEORETICAL FRAMEWORK}

\subsection{The Concept of Inclusive Development}

Inclusive development has become an international issue, evident from its association with sustainable development, both in Sustainable Development Goal's (SDG's) and New Urban Agenda-Habitat III (NUA). This is because the core of inclusive development is equity in getting services to the community, including infrastructure, facilities, even socio-economic equity.

Inclusive development approach emphasizes justice and social justice, and participation in development originating from the exclusion of development, marginalization and inequality (Beall \& Fox; Figueiredo \& Perkins; Sachs; Sultana in Kooy, 2018). Inclusive development is planning for all, open, minimize gender and economic discrimination, ensuring that all citizens have access to improve the quality of the environment where the implementation process is conducted jointly between the government and the community. (Savitri R. and Adriyan D, 2013).

\subsection{Principles of Inclusive Development}

Asian Development Bank (2017), states that the basic principles of inclusive city development include; accessibility, affordability, resilience, and sustainability.

- Accessibility; opportunities for safe and secure housing, basic services for all individuals and communities structured into projects and programs.

- Affordability; not only are the affordability of families benefiting from house, service, and transportation solutions, but also the affordability of governments to provide it.

- Resilience; a proactive approach to strengthening communities' ability to resist, recover, and reorganize in response to disasters without endanger the viability and socio-economic.

- Sustainability; related to community or government role in maintaining program sustainability, such as; operate, maintain, update, or expand infrastructure services.

In addition, Word Bank (2017) explains that inclusive development should address needs based on local conditions, such as age (children, youth, the elderly), gender, and differently abled groups. 


\subsection{Physical Aspects of Inclusive Development}

In order to ensure that the future city is able to provide better opportunities and living conditions for everyone, it is important to understand that the concept of inclusive city involves of physical, social and economic factors. This research more focused on physical factor as physical aspect related to infrastructure provision. World Bank (2015) explained that physical dimensions consist of access to land, housing, and infrastructure with the following explanation;

- Access to land as a fundamental factor for encouraging inclusion. Tenure, land use planning, and land financing are some tools that can help in achieving inclusion.

- Housing and infrastructure provision also have a role in ensuring inclusion and economic growth.

- Services such as water and sanitation are important to ensure public health. Transportation are also important because of their impact on mobility, asset development and community image.

Furthermore, Mc Granahan, et al (2016) argues that empowerment and equity of inclusion not only against clear discrimination, but also eliminates disadvantage that structurally created from exclusion. From this perspective, there are three levels of inclusion;

- Remove discriminatory exclusions, such as denying migrants the right to settle in the city (spaces), buying property (markets), access to schools and health care (services)

- Ensure that governments regulate markets, provision of services and use of space; and taking into account the needs of disadvantaged groups

- Ensure that the human rights of disadvantaged groups can be met in several ways, including providing access to markets, services, and access to space.

\subsection{Physical Characteristic of Slums}

Slums are unstructured (e.g. irregular and unregulated homes, unavailability of public facilities, clean water and sanitation facilities), improper physical form, for example regularly flooded every year (Santosa in Wijaya, 2007).

Cronin in Elrayies (2016), slums are characterized by excessive population density, poor housing, lack of sanitation and clean water, and physical and legal insecurity. Slum dwellings can be interpreted as a residential environment whose quality is very unfit for habitation, with the following characteristics: slums are on land that is not in accordance with the physical, very high building density in very limited area, prone to social diseases and environmental diseases, the quality of the building is low, not served adequate environmental infrastructure and endanger the survival and livelihood of its inhabitants (Budiharjo, in Heryati 2008).

Based on the description, it can be interpreted that the slum characteristic is the density of housing and the low level of basic housing infrastructure services related to the inability of the community to provide adequate housing and the inadequate provision of adequate infrastructure by the government. On the other hand, the condition is also influenced by the rapid development of the area, thus creating dense housing. Furthermore, what if the concept of inclusive development is linked in dealing with slum, especially that area in the around of rapidly growing urban service centers.

\section{METHODS}

This research is a case study, that can be explorative and descriptive, focus on trying to answer questions, how and why, and also answer what questions (Yin, 1993). This research used a mixed methods approach that focusing on collecting, analyzing, and mixing quantitative and qualitative data study, with the primary assumption being that the use of quantitative and qualitative approaches provides a better understanding of research problems than using one approach (Cresswell and Clark, 2011). Primary data obtained through observation and interviews, while secondary data obtained with a compilation of data from the Krajan Kampung Government. The determination of concept and strategy is done by SWOT analysis.

\section{RESULTS}

Related to the objectives of the research, this discussion more focused on public facilities and application of inclusive development principles. Public facilities such as; neighborhood's road, drainage, waste, open space, and health, education, worship, and transportation facilities. Furthermore, the principles of inclusive development to be discussed include: accessibility, affordability, resilience, and sustainability.

\subsection{Community profile}

Following the profile of the Krajan Kampung community based on Monograph / Krian Kampung's profile 2017 data from the government.

a. Gender

The population of Krajan kampung is 2588 people, consisting of 1268 men and 1320 women. Currently, there are no genderrelated issues in development infrastructure or settlement facilities.

b. Age

Based on age group, most of the society included in adult group (39,80\%) and elderly (37.04\%), while others are included in the children and teens. Age-related development issues are the absence of open space facilities (sports, entertainment, or socialization) for age groups. The condition is related to the lack of open space due to high building density. 
Table 1.1 Age group in Krajan Kampung in 2017

\begin{tabular}{|l|r|r|}
\hline \multicolumn{1}{|c|}{ Age group* } & Total (people) & Percentage (\%) \\
\hline Children (0-11) & 210 & $8.12 \%$ \\
\hline Teens (12-25) & 389 & $15.04 \%$ \\
\hline Adult (26-45) & 1030 & $39.80 \%$ \\
\hline Elderly (45 - > 65+) & 959 & $37.04 \%$ \\
\hline Total & 2588 & $100.00 \%$ \\
\hline
\end{tabular}

*Age group by health department of indonesia, 2009

\section{c. Welfare}

People who work amount 703 people, while others are children, students, the elderly, and people who have not worked.Most of the people's livelihoods are merchants (465 people) and factory employees (203 people). while the rest are government employees (15 people), agriculture (10 people), construction workers ( 8 people), and excavation ( 2 persons). This condition, indicating that the existence of trading areas (including Krian's Market) and industry provides jobs and economic resources of local communities. The total number of households in Krajan Kampung is 636 households. If viewed by welfare, 212 households $(30.16 \%)$ including poor households.

\subsection{Public or Communal Facilities}

Based on observation and interviews, the condition of public or communal facilities in Krajan Kampung are as follows.

a. Neighborhood's road

All settlement area has been connected by access, although it is a alley with width about1-2 meters, it is also related to the dense condition of the building. There are still streets with broken pavement (paving, concrete) and ground (none hardened), not equipped with drainage. Most of the neighborhood's roads don't have lights.

b. Drainage

There are several roads that are equipped with drainage. But, there are drainages that not connected with the others, or the residential areas do not have drainage. Most of the drainage has sedimentation and clogging garbage, so that runoff water cannot flow smoothly. Beside, there are still drainage that have been damaged or not yet built. Moreover, this area is prone to flooding, because drainage in the Krian's market (north of Krajan Kampung) are not managed properly and covered by garbage. This condition causes the water runoff, thus overflowing into the settlement area.

c. Waste management

There is the development of Integrated Waste Disposal Site by government which is located in east of Krajan Kampung. However, infrastructure and facilities for the operation of Integrated Waste Disposal Site are still inadequate, considering that currently available facilities are still only the building, without a complete infrastructure. In settlement area, there is no regular waste collection/ carriage. The main means of supporting the garbage is not yet available, especially garbage bins, garbage transport vehicles, and janitor. Settlement area that around the river or drainage, there are still residents who throw garbage into the river or drainage. Furthermore, existence of temporary dump site in Krian's Market still not optimal, considering there is still a lot of garbage that have not been handled and located around the market so that around settlement area are impacted.

d. Open space

As settlement with high density building, the presence of open space public is still small. It causes neighborhood's road or alleys to be used as open spaces, such as children's playground and social space However, there a potential development the park in front of the village government office and land around the river border can be utilized as green open space. In addition, there is actually a multipurpose building (located in a village office complex) that can be used for community activities but is currently damaged and used as a car park area.

e. Health, education, worship, and transportation facilities

Krajan Kampung located around the center of the activity, so the facilities are available quite complete. Health facilities is Krian's Community Health Center which located in the north. Educational facilities are available in Krajan Kampung are kindergarten - play group and junior high school, while elementary school and senior high school are located in the north and east. Worship facilities are available in Krajan Kampung is musholla (small mosque), while the nearest mosque and church are in the west and south. The available transportation facilities are sub terminals located in Krian's Market area as well as railway station on the east side of Krian's Market.

\subsection{Accessibility, Affordability, Resilience, and Sustainability}

Based on observation and interviews, following conditions of accessibility, affordability, resilience, and sustainability in Krajan Kampung.

a. Accessibility

Most land ownership status and community buildings are property rights, except for households who rent a house. Existing accessibility issues are; the inability of poor households to provide basic infrastructure, such as; decent house and proper sanitation. it is related to their small income or economy condition and uncertain jobs. 
Community accessibility to education and health facilities is adequate. There is a educational and healthy cost assistance from the government, especially for the poor. In addition, worship and transportation facilities are also easily accessible by the community.

b. Affordability

Generally, government assistance in improving settlements in the form of neighborhood's road construction, drainage, house and sanitation improvement. However, the number and distribution are still small and uneven, so there are still many people who have not been able to feel the benefits.

c. Resilience

The threat of disaster that occurred in Krajan Kampung are flood and fire. Flood arise due to inappropriate drainage, such as; sedimentation, the presence of uneven drainage, and drainage that has not been connected to each other. In addition, flooding is also caused by runoff water coming from Krian's Market, due to unmanaged drainage (clogged by garbage). While, high degree of vulnerability to fire related to the lack of fire infrastructure, high building density, and inadequate accessibility (road dimension about 1-2 meters). Furthermore, fire infrastructures are not yet available, such as hydrants, fire extinguishers.

d. Sustainability

The problem of sustainable is the absence of maintenance and supervision of the infrastructure of settlements that have been built by the government. therefore, over time the infrastructure is damaged and there is no improvement due to lack of available funds.

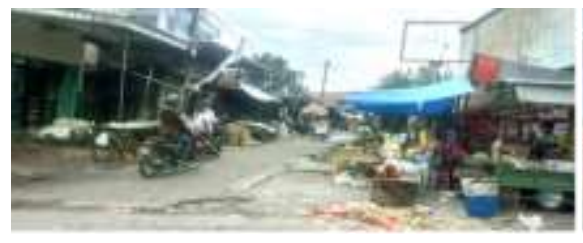

Krian's Market
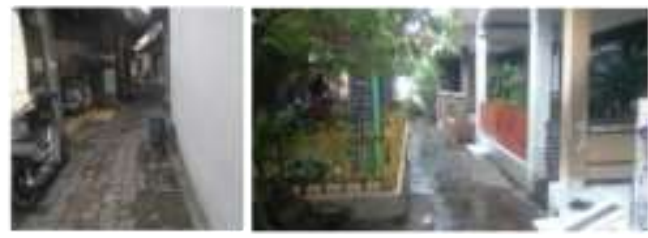

Alleys without drainage

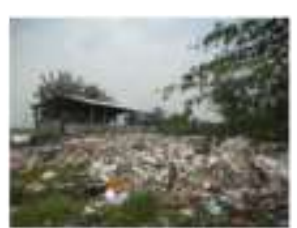

Garbage at Integrated Waste Disposal
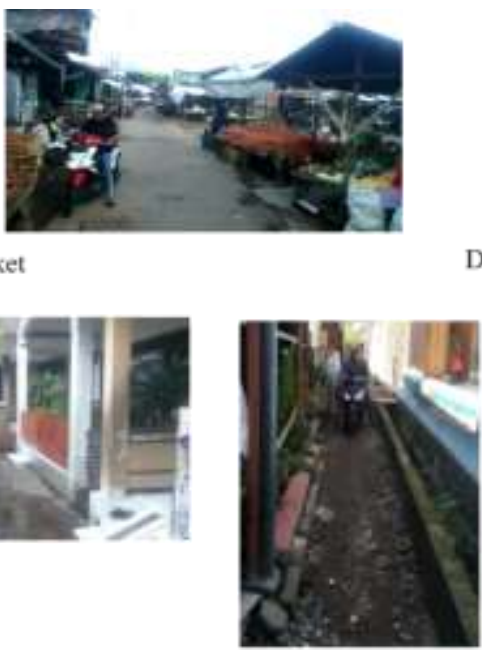

Alleys that has not been hardened

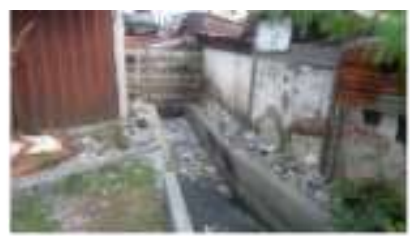

Drainage clogging by garbage in Krian's Market

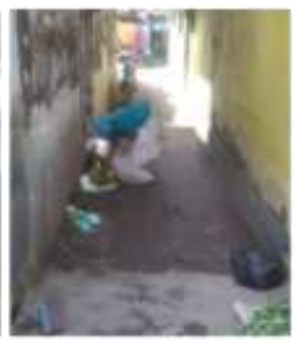

not been hardened

Figure 1.2 Conditions of some facilities

\section{DISCUSSION}

\subsection{Application of Inclusive Concept}

As inclusive development has become an international issue, there have been studies related to the application of inclusive concepts in other locations. In the research of Towards Inclusive and Sustainable Transformation In Shenzhen: Urban Redevelopment, Displacement Patterns of Migrants and Policy Implications by Liu, et al (2016), describes an inclusive economic, physical and social planning strategy and provides direction for transforming the 'village in the city' sustainable in Shenzhen, among others:

- Economic inclusion can be achieved by supporting the informal economy in 'village in the city' and the restructuring of industrial and economic activities in collective land, so that migrants can participate / integrate in market activities.

- Physical inclusion can be done through a gradual increase in roads, the addition of public infrastructure and facilities and housing to migrants, which will strengthen migrants access to redistributive resources.

- Social inclusion can be facilitated through the participation and empowerment of migrants in the process of enhancing the area, utilizing the unique reciprocal characteristics and valuable social assets associated with 'village in the city'.

In the context of this research, the strategies on above can also be applied, because the 3 (three) strategies (economic, physical and social inclusion) are aspects of inclusive development by the World Bank (2015). If linked in the framework of Principles of Inclusive Development (Asian Development Bank, 2017), which consists of: accessibility, affordability, resilience, and sustainability, that strategies are incomplete. The principle of accessibility and affordability is already included in the strategy described, but in that strategies have been no detailed explanation of how the application of resilience, and sustainability. In addition, the research has not discussed the concept of equality in inclusive development, i.e. age, gender, and differently abled groups. 
Therefore, in this research, it is necessary to complement with some incomplete aspects, which are associated with local conditions.

\subsection{SWOT Analysis}

In this research, strategy of developing inclusive kampung was carried out by using SWOT analysis in accordance with the conditions of the local area that were linked to the concepts and principles of inclusive development.

Table 1.2. SWOT Analysis

\begin{tabular}{|c|c|c|}
\hline & $\begin{array}{l}\text { Strength } \\
\text { 1) Health, education, worship, } \\
\text { and transportation facilities } \\
\text { are available quite complete } \\
\text { 2) Most land and building } \\
\text { ownership status is property } \\
\text { rights. } \\
\text { 3) The existence of alleys used } \\
\text { by the community as a } \\
\text { children's playground and } \\
\text { socialization place }\end{array}$ & $\begin{array}{l}\text { Weakness } \\
\text { 1) There are neighborhood's roads and alleys } \\
\text { damaged, not hardened, and street lighting is not } \\
\text { yet available } \\
\text { 2)Drainage has not reached all settlements, not } \\
\text { connected to each other, sedimentation that caused } \\
\text { flooding } \\
\text { 3) Waste infrastructure is incomplete, there is no } \\
\text { waste carriage } \\
\text { 4) There is not enough open space for the age group } \\
\text { 5) Incapacity of poor households (30.16\%) in } \\
\text { providing basic infrastructure due to small income } \\
\text { and uncertain jobs } \\
\text { 6) Prone to fire disasters and unavailability of fire } \\
\text { extinguishers } \\
\text { 7) Flood disaster compounded drainage condition } \\
\text { that is not well managed, sedimentation, and } \\
\text { clogging by garbage in Krian's Market } \\
\text { 8) Waste management in Krian's Market is } \\
\text { inadequate so impacted on the settlement. } \\
\text { 9)Infrastructure in Integrated Waste Disposal is not } \\
\text { yet complete }\end{array}$ \\
\hline $\begin{array}{l}\text { Opportunity } \\
\text { 1) There is Integrated Waste Disposal } \\
\text { development by government. } \\
\text { 2) Potential of open space development } \\
\text { and utilization of Multipurpose } \\
\text { Building in village office area. } \\
\text { 3) The government has provided } \\
\text { assistance in improving } \\
\text { infrastructure, such as roads, } \\
\text { drainage and housing } \\
\text { 4) Government assistance in education } \\
\text { and health costs }\end{array}$ & $\begin{array}{l}\text { Strategy S-O } \\
\text { - Alleys improvement with } \\
\text { greenery (plant) and painting, } \\
\text { so it is more comfortable to be } \\
\text { used as play area and place of } \\
\text { socialization } \\
\text { - Maintaining the existence of } \\
\text { government assistance, both } \\
\text { for infrastructure, education } \\
\text { and health cost. }\end{array}$ & $\begin{array}{l}\text { Strategy W-O } \\
\text { - Improvement of neighborhood's roads and alleys } \\
\text { and lighting supply } \\
\text { - Development and improvement of integrated } \\
\text { drainage } \\
\text { - Completing the waste infrastructure and } \\
\text { implementing the waste carriage system to } \\
\text { Integrated Waste Disposal. } \\
\text { - Development of park in front of village office, can } \\
\text { be equipped with play ground } \\
\text { - Multipurpose building improvements, can be used } \\
\text { as a sports hall (indoor) } \\
\text { - Increasing income of the poor, through the } \\
\text { empowerment of the local economy } \\
\text { - Disaster response community training and } \\
\text { provision of fire extinguishers }\end{array}$ \\
\hline $\begin{array}{l}\text { Threat } \\
\text { 1) Government infrastructure } \\
\text { improvement assistance is still } \\
\text { uneven and lack of supervision and } \\
\text { maintenance after improvement }\end{array}$ & $\begin{array}{l}\text { Strategy S-T } \\
\text { - Improvements in the } \\
\text { management and quality of } \\
\text { drainage and waste by Krian's } \\
\text { Market manager. } \\
\text { - Completing Infrastructure in } \\
\text { Integrated Waste Disposal in } \\
\text { order to operate maximally }\end{array}$ & $\begin{array}{l}\text { Strategy W-T } \\
\text { - Increased coverage of infrastructure improvements } \\
\text { as well as routine supervision and repair by the } \\
\text { government } \\
\text { - Establish community self-help groups that work } \\
\text { with government, play a role in monitoring and } \\
\text { improving infrastructure. }\end{array}$ \\
\hline
\end{tabular}

\section{CONCLUSION}

Based on the results of the analysis, can be determined strategies development of inclusive Krajan Kampung settlement as follows.

1. Improving the quality and provision of public or communal facilities 
- Alleys improvement with greenery (plant) and painting, so it is more comfortable to be used as play area and place of socialization

- Improvement of neighborhood's roads and alleys and lighting supply. It also facilitates access to differently abled groups.

- Development and improvement of integrated drainage

- Completing the waste infrastructure and implementing the waste carriage system to Integrated Waste Disposal.

- provision of open space; development of park in front of village office, can be equipped with playground; and multipurpose building improvements, can be used as a sports hall (indoor)

2. Increasing performance of accessibility, affordability, resilience, and sustainability

- Accessibility; increasing income of the poor, through the empowerment of the local economy

- Affordability; maintaining the existence of government assistance, both for infrastructure, education and health cost and; completing Infrastructure in Integrated Waste Disposal in order to operate maximally

- Resilience; disaster response community training and provision of fire extinguishers

- Sustainability; increased coverage of infrastructure improvements as well as routine supervision and repair by the government, and; establish community self-help groups that work with government, play a role in monitoring and improving infrastructure.

3. Cooperate with the of Krian's Market manager as one of the causes of the slum settlement

- Improvements in the management and quality of drainage and waste by Krian's Market manager.

\section{REFERENCES}

[1] Asian Development Bank. 2017. Enabling Inclusive Cities: Tool Kit for Inclusive Urban Development. 2017 Asian Development Bank

[2] Creswell, J. W., \& Plano Clark, V. L. (2011). Designing and conducting mixed methods research (2nd ed.). Thousand Oaks, CA: Sage Publications, Inc.

[3] Elrayies, Ghada Mohammad. 2016. Rethinking Slums: An Approach for Slums Development towards Sustainability. Journal of Sustainable Development; Vol. 9, No. 6; 2016. ISSN 1913-9063 E-ISSN 1913-9071. Published by Canadian Center of Science and Education.

[4] Joshua, Phanuel B. dan George Godwin Glanda. 2016. Slum Conditions in Urban Nigeria: A Case of Jimeta-Yola, Adamawa State, Nigeria. Journal of Environment and Earth Science ISSN 2224-3216 (Paper) ISSN 2225-0948 (Online) Vol.6, No.3, 2016. www.iiste.org

[5] Kooy, et al.2018.Inclusive development of urban water services in Jakarta: The role of groundwater. Habitat International 73 (2018) 109e118. http://dx.doi.org/10.1016/j.habitatint.2016.10.006.

[6] Liu, et al. 2016. Towards inclusive and sustainable transformation in Shenzhen: Urban redevelopment, displacement patterns of migrants and policy implications. www.elsevier.com/ locate/jclepro, http://dx.doi.org/10.1016/j.jclepro.2016.09.224

[7] Mcgranahan, et al, (2016). Inclusive urbanization: Can the 2030 Agenda be delivered without it? Environment \& Urbanization Copyright (C) 2016 International Institute for Environment and Development (IIED). 13 Vol 28(1): 13-34. DOI: 10.1177/0956247815627522 www.sagepublications.com

[8] Monograph / Krian Kampung's Profile. Krian Kampung's Government. 2017

[9] Savitri R, Raisa dan Adriyan D, Rendy. 2013. Perencanaan Kota Inklusif Studi Kasus : Kota Ahmedabad Parivartan, India; Kota Ramah Lansia - New York, Amerika Serikat; dan Kota Ramah Anak Sidoarjo, Indonesia. Prosiding Penyelenggaraan Seminar Nasional Dalam Rangka Habitat Dunia - Kota Untuk Semua

[10] United Nation Conference on Housing and Sustainable Urban Development. Habitat III New Urban Agenda. 2016.

[11] United Nation. Transforming Our World: The 2030 Agenda For Sustainable Development

[12] Wijaya, Donny Wahyu .2016. Perencanaan Penanganan Kawasan Permukiman Kumuh Studi Penentuan Kawasan Prioritas Untuk Peningkatan Kualitas Infrastruktur Pada Kawasan Pemukiman Kumuh Di Kota Malang. Jurnal Ilmiah Administrasi Publik (JIAP)

[13] World Bank. 2015. Inclusion Matters: The Foundation for Shared Prosperity. Washington, DC. (C) World Bank.

[14] Yin, Robert K, "Study Research: Design and Methods", Raja Grafindo Persada, 2003 